\title{
Conceptual Progression in Innovative Learning Spaces
}

New Zealand Journal of Teachers' Work, Volume 12, Issue 1, 6-8, 2015

\author{
GRAHAM MCPHAIL \\ Faculty of Education \\ The University of Auckland
}

\begin{abstract}
Recent discussions in the media in relation to the design of school classrooms highlight the way in which physical spaces are symbolic of deeper ideas about education. Desks and chairs arranged with a focal point at the front of a classroom may suggest a teacher-centred pedagogy where a standardised delivery of the curriculum takes priority over the individual learning needs of students. The Ministry of Education's newly favoured innovative learning environments include open plan classrooms with glass, natural light, moveable walls, breakout spaces and moveable furniture. These spaces are suggestive of student-centred pedagogy, where learners are able to move around freely, connect with each other and with the teacher, and to access the Internet as required by the context and demands of the learning. While learning spaces can certainly add much to a positive ambience and facilitate different pedagogical approaches (such as group learning or individual work) there is no inherent link between classroom design and educational outcomes. The Ministry's blanket advocacy for such spaces needs to be approached with caution as there is a risk of such visions becoming idealised.

If schools dive straight into the curricular and pedagogical approaches implied by these new learning spaces, for example interdisciplinary and projectbased learning, there is a danger that teachers may not be sufficiently wellequipped to be leaders of learning. What is it about such pedagogical approaches that requires caution? Firstly, in the case of interdisciplinary learning, making deep connections between subject areas requires teachers to have advanced understanding of both foundational and threshold concepts of a subject before meaningful links across disciplines are likely to occur. In recent research in a $21^{\text {st }}$ century school, teachers identified the unpacking of such concepts as one of the most difficult aspects of moving towards a new curricular model (McPhail, under review). Secondly, in relation to individual student-led project work, the design and tracking of conceptual progression within a subject comes to the foreground (Rata, 2015; Winch, 2013). If a teacher is leading thirty learners through individual projects, how can conceptual progression be managed, let alone ensured?

Educational issues, such as ongoing underachievement amongst some groups in society, are the result of the interaction of complex forces. Media reporting tends to represent discussions in a polarised way (see Johnston, 2015; Morris, 2015; and Walters, 2015) but solutions are likely to emerge from nuanced thinking rather than traditional-versus-progressive binary conceptions.
\end{abstract}


The design of learning spaces is only one of the aspects we should be considering in relation to in-school factors. The longitudinal research of Morais and Neves (2011) suggests drawing on a combination of both 'traditional' and 'progressive' approaches in order to increase achievement with all students. In their model there is a personalised learning environment where students feel valued and confident to question, discuss, and share ideas. In regards to pacing the model suggests a 'progressive' approach whereby students are given more individual control over the time needed to assimilate, develop, and utilise new knowledge. In the model, a more 'traditional' approach is required in relation to curricular selection, including its sequence and evaluation. The teacher is present as an expert who oversees the selection and sequencing of content and then guides the student along the path of conceptual progression through strongly framed evaluative criteria and an engaging pedagogy.

We can logically see that certain learning spaces may well be conducive to broadened and more student-centred approaches. But they are not in themselves critical. What is pivotal is the teacher's ability to provide a positive learning environment, detailed and effective feedback derived from deep knowledge of disciplinary conceptual progression, and time for students to assimilate and work with new knowledge. The challenge in innovative learning spaces and enquiry-based approaches is to ensure the conceptual progression is positioned at the centre of students' and teachers' work (McPhail \& Rata, 2015). The Ministry would do well to support the development of teacher knowledge which becomes, somewhat ironically, ever more critical in studentcentred learning spaces. I'm sure we all hope that such 'classrooms' will be filled with more than just aspirations. 


\section{REFERENCES}

Johnston, K. (2015, May 11). Grammar eschews beanbag lessons in $\$ 6 \mathrm{~m}$ classroom upgrade. New Zealand Herald. Retrieved from http://www.nzherald.co.nz/nz/news/article.cfm?c id =1\&objectid=1144645 1

McPhail, G. (under review). From aspirations to practice: challenges for a new 21st Century secondary school.

McPhail, G., \& Rata, E. (2015). Two Curriculum Models: 'Progressive Knowledge' and '21st Century Learning', New Zealand Journal of Educational Studies, http://link.springer.com/article/10.1007/s40841-0150025-9

Morais, A. M. \& Neves, I. P. (2011) Educational texts and contexts that work: Discussing the optimization of a model of pedagogic practice. Available online

at: http://essa.ie.ul.pt/ficheiros/artigos/livros/2011Educationaltextsandcontex tsthatwork.pdf

Morris, J. (2015, May 15). Grammar wise to steer clear of the 'one size fits all' classrooms. New Zealand Herald. Retrieved from http://www.nzherald.co.nz/nz/news/article.cfm?c id=1\&objectid=1144881 6

Rata, E. (2015) A pedagogy of conceptual progression and the case for academic knowledge. British Educational Research Journal, DOI: 10.1002/berj.3195

Walters, L. (2015, October, 18). Top schools give multi-million dollar classrooms a fail grade. Sunday Star Times. Retrieved from http://www.stuff.co.nz/national/education/73042309/Top-schools-givemulti-million-dollar-classrooms-a-fail-grade

Winch, C. (2013). Curriculum design and epistemic ascent. Journal of Philosophy of Education, 47(1), 128-146.

The opinions expressed are those of the paper author(s) and not the New Zealand Journal of Teachers' Work. Copyright is held by individual authors but offprints in the published format only may be distributed freely by individuals provided that the source is fully acknowledged. [ISSN-1176-6662] 